\title{
Role of Tumor-Associated Macrophages in Sarcomas
}

\author{
Tomohiro Fujiwara ${ }^{1,2, * \mathbb{D}}$, John Healey ${ }^{2}$, Koichi Ogura ${ }^{2}$, Aki Yoshida ${ }^{1}{ }_{\mathbb{D}}$, Hiroya Kondo ${ }^{1}$, Toshiaki Hata ${ }^{1}$,

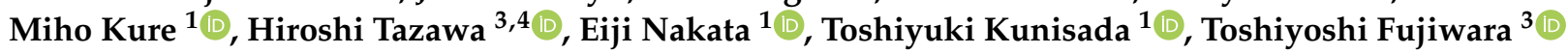 \\ and Toshifumi Ozaki ${ }^{1}$
}

1 Department of Orthopaedic Surgery, Okayama University Graduate School of Medicine, Dentistry and Pharmaceutical Sciences, Okayama 700-8558, Japan; akysda@gmail.com (A.Y.); me20034@s.okayama-u.ac.jp (H.K.); toshiakih1080@gmail.com (T.H.); miho.suzuki0000@gmail.com (M.K.); eijinakata8522@yahoo.co.jp (E.N.); toshi-kunisada@umin.ac.jp (T.K.); tozaki@md.okayama-u.ac.jp (T.O.)

2 Department of Surgery, Orthopaedic Service, Memorial Sloan Kettering Cancer Center, New York, NY 10065, USA; healeyj@MSKCC.ORG (J.H.); ogura-tky@umin.ac.jp (K.O.)

3 Department of Gastroenterological Surgery, Okayama University Graduate School of Medicine, Dentistry and Pharmaceutical Sciences, Okayama 700-8558, Japan; htazawa@md.okayama-u.ac.jp (H.T.); toshi_f@md.okayama-u.ac.jp (T.F.)

4 Center for Innovative Clinical Medicine, Okayama University Graduate School of Medicine, Dentistry and Pharmaceutical Sciences, Okayama 700-8558, Japan

* Correspondence: tomomedvn@okayama-u.ac.jp

check for updates

Citation: Fujiwara, T.; Healey, J.; Ogura, K.; Yoshida, A.; Kondo, H.; Hata, T.; Kure, M.; Tazawa, H.; Nakata, E.; Kunisada, T.; et al. Role of Tumor-Associated Macrophages in Sarcomas. Cancers 2021, 13, 1086. https://doi.org/10.3390/cancers 13051086

Academic Editors: Judith Bovée and Torsten Kessler

Received: 31 December 2020

Accepted: 17 February 2021

Published: 3 March 2021

Publisher's Note: MDPI stays neutral with regard to jurisdictional claims in published maps and institutional affiliations.

Copyright: (c) 2021 by the authors. Licensee MDPI, Basel, Switzerland. This article is an open access article distributed under the terms and conditions of the Creative Commons Attribution (CC BY) license (https:// creativecommons.org/licenses/by/ $4.0 /)$.
Simple Summary: Recent studies have shown the pro-tumoral role of tumor-associated macrophages (TAMs) not only in major types of carcinomas but also in sarcomas. Several types of TAM-targeted drugs have been investigated under clinical trials, which may represent a novel therapeutic approach for bone and soft-tissue sarcomas.

Abstract: Sarcomas are complex tissues in which sarcoma cells maintain intricate interactions with their tumor microenvironment. Tumor-associated macrophages (TAMs) are a major component of tumor-infiltrating immune cells in the tumor microenvironment and have a dominant role as orchestrators of tumor-related inflammation. TAMs promote tumor growth and metastasis, stimulate angiogenesis, mediate immune suppression, and limit the antitumor activity of conventional chemotherapy and radiotherapy. Evidence suggests that the increased infiltration of TAMs and elevated expression of macrophage-related genes are associated with poor prognoses in most solid tumors, whereas evidence of this in sarcomas is limited. Based on these findings, TAM-targeted therapeutic strategies, such as inhibition of CSF-1/CSF-1R, CCL2/CCR2, and CD47/SIRP $\alpha$, have been developed and are currently being evaluated in clinical trials. While most of the therapeutic challenges that target sarcoma cells have been unsuccessful and the prognosis of sarcomas has plateaued since the 1990s, several clinical trials of these strategies have yielded promising results and warrant further investigation to determine their translational benefit in sarcoma patients. This review summarizes the roles of TAMs in sarcomas and provides a rationale and update of TAM-targeted therapy as a novel treatment approach for sarcomas.

Keywords: sarcoma; tumor-associated macrophage; prognosis; clinical trial; immunotherapy

\section{Introduction}

Sarcomas, which are broadly categorized as bone sarcomas or soft-tissue sarcomas, represent a clinically and molecularly heterogeneous group of mesenchymal malignancies with more than 50 histological subtypes [1-3]. While wide surgical resection is a mainstay of treatment for sarcomas, multidisciplinary treatments with multiagent chemotherapy and/or radiotherapy are performed according to the histological diagnosis. The introduction of systemic chemotherapy in the 1970s-1980s substantially improved the prognosis of patients with osteosarcoma, which is the most common primary bone sarcoma [4-6]. Since 
then, enormous effort has been made to develop novel drugs; however, effective therapies have not emerged, and the prognosis for sarcomas has plateaued since the 1990s [4]. For soft-tissue sarcomas such as myxoid liposarcoma and synovial sarcoma, doxorubicin is the only drug that has been demonstrated to be effective for survival, but the benefit is limited. Some molecular targeted drugs, such as pazopanib, trabectedin, and eribulin, have been recently approved by the U.S. Food and Drug Administration (FDA), but these therapies do not have a substantial cure rate [7].

Most of the therapeutic challenges targeting sarcoma cells have failed. Unfortunately, recent introduction of emerging anti-PD-1 immunotherapy to treat sarcomas has resulted in a poor response [8,9]. An alternative strategy is to target cells in the sarcoma microenvironment. Tumor-associated macrophages (TAMs) are major components in the tumor microenvironment and have a dominant role as orchestrators of cancer-related inflammation [10-12]. Several preclinical approaches targeting TAMs or inhibiting their tumor-promoting functions have been successful and are regarded as promising therapeutic strategies following the development of immune checkpoint inhibitors [13-20]. In this review, we summarize the roles of TAMs and their clinical relevance in sarcomas, and provide an update on recent therapeutic advancements targeting sarcoma TAMs. We searched articles published until December 2020 in PubMed using the following terms: "macrophage," "tumor-associated macrophage," "sarcoma," "bone sarcoma," "soft-tissue sarcoma," and histological diagnosis terms, such as "osteosarcoma," "Ewing sarcoma," "chondrosarcoma," "leiomyosarcoma," "liposarcoma," "undifferentiated sarcoma," "synovial sarcoma," and "dermatofibrosarcoma protuberans," in various combinations. Abstracts of the manuscripts in English were reviewed for relevance. Studies reporting the prognostic value of TAMs in bone and soft-tissue sarcomas were all included. Finally, we searched ClinicalTrials.gov for clinical trials with TAM-targeted drugs.

\section{Role of Tumor-Associated Macrophages (TAMs)}

Among the innate and adaptive immune cells that are recruited to the tumor microenvironment, macrophages are particularly abundant and influence tumor growth and progression [10-12]. There are multiple precursors of TAMs, including circulating blood monocytes, monocyte-related myeloid-derived suppressor cells (M-MDSCs), and tissue-resident macrophages [11]. They are recruited to the tumor sites in response to cytokines (such as colony stimulating factor (CSF)-1, interleukin (IL)-34, and members of the vascular endothelial growth factor (VEGF) family) and chemokines (such as chemokine C-C motif ligand 2 (CCL2) and CCL5) and differentiate into TAMs [11]. In general, monocytes/macrophages can be polarized to M1-like (classically activated) or M2-like (alternatively activated) macrophages [12]. TAMs typically display a pro-tumorigenic phenotype associated with the M2-like profile, whereas the anti-tumorigenic function is associated with the M1-like phenotype [21].

TAMs play specialized functional roles in tumor progression, including cancer progression, metastasis, angiogenesis, and immune suppression (Figure 1) [12]. TAM-derived IL-6 and mitogens promote the occurrence and development of hepatocellular carcinoma via activation of signal transducer and activator of transcription 3 (STAT3) and nuclear factor kappa B (NF- $\mathrm{kB}$ ) signaling, respectively, which also promote resistance to chemotherapy $[22,23]$. Similarly, the presence of TAM-derived inflammatory cytokines IL-23 and IL-17 are associated with tumor progression [24]. TAM expressions of IL-6 and tumor necrosis factor (TNF)- $\alpha$ promote resistance to chemotherapy and targeted agents [25]. Several TAM-produced proteases, including cathepsin B, matrix metalloproteinase (MMP)-2, MMP-7, MMP-9, and the extracellular matrix (ECM), contribute to tumor invasion and metastasis [26]. Tumor angiogenesis is promoted by the VEGF, TNF- $\alpha$, IL-1 $\beta$, IL-8, plateletderived growth factor (PDGF), basic fibroblast growth factor (bFGF), and MMPs, which are produced by TAMs [27]. TAMs can also promote the immunosuppressive activity of regulatory T cells through IL-10 and transforming growth factor (TGF)- $\beta[10,28]$. TAMs often express programmed death-ligand 1 (PD-L1)/L2, B7-H4, and V-domain Ig suppressor of T 
cell activation (VISTA), which trigger the inhibitory PD-1-mediated immune checkpoint in T cells $[11,29,30]$.

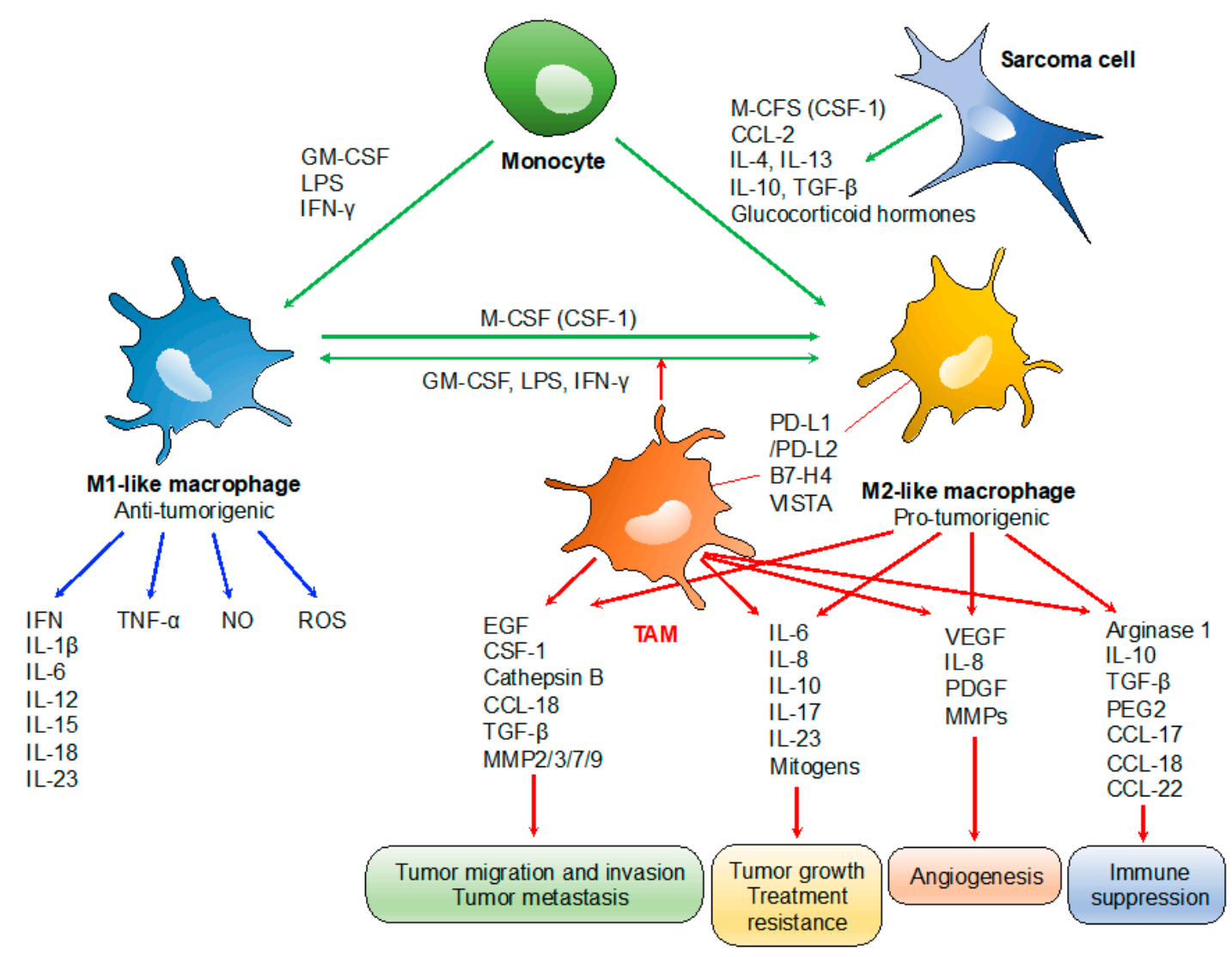

Figure 1. Roles of tumor-associated macrophages (TAMs) in tumor progression. TAMs typically display a pro-tumorigenic phenotype associated with the M2-like profile. Tumor growth: TAM-derived IL-6/IL-17/IL-23 and mitogens promote tumor growth and treatment resistance via activation of STAT3 and NF- $\mathrm{KB}$ ) signaling, respectively. Tumor migration, invasion and metastasis: TAM-derived proteases such as cathepsin B, MMP-2, -3, -7, and -9; and chemokines/cytokines such as CCL-18 and epidermal growth factor (EGF) contribute to tumor invasion and metastasis. Angiogenesis: tumor angiogenesis is promoted by the TAM-derived VEGF, IL-8, PDGF, and basic fibroblast growth factor (bFGF), MMPs. Immunosuppression: IL-10 and TGF- $\beta$ derived from TAMs promote the immunosuppressive activity of regulatory T cells. PD-L1/L2, B7-H4, and VISTA expressed on TAMs trigger the inhibitory PD-1-mediated immune checkpoint in T cells.

Regarding the clinical significance of TAMs, a high density of M2-like TAMs in the tumor microenvironment is associated with a poor survival outcome in many types of malignant tumors [11,31,32]. The common markers for M1-like TAMs in human samples are human leucocyte antigen (HLA)-DR, inducible nitric oxide synthase (iNOS), and pSTAT1. On the other hand, common markers for M2-like TAMs are CD163, CD204, and CD206, attributable to the high expression of the mannose receptor-1 (CD206) and macrophage scavenger receptors (CD163 and CD204) by the M2-like TAMs [12]. In patients with breast cancer, a high density of $\mathrm{CD}_{163}{ }^{+}$macrophages has been associated with poor histological grade, hormonal receptor negativity, lymph node metastasis, and poor survival outcome [33]. Zhang et al. developed a meta-analysis with 55 studies, where they evaluated the correlation between the TAM infiltration and clinical prognosis. They showed the adverse effects of TAMs on survival in breast, gastric, bladder, ovarian, oral, and thyroid cancer patients in their results. In contrast, they observed positive effects of TAMs on survival in patients with colorectal cancer [32]. Evidence suggests that increased inflammation-related gene expressions, especially those related to the polarization of macrophages, are also associated with poor survival [16]. However, there are conflicting data for several types of cancers, such as stomach and prostate cancer [32]. 
These are possibly related to the type of analysis performed (e.g., quantitation of stromal versus intratumoral macrophages), the stage of cancer evaluated, or the use of different macrophage markers.

\section{Clinical Relevance of the Infiltration of TAMs in Bone Sarcomas}

\subsection{Osteosarcoma}

Osteosarcoma is the most common primary malignancy of bone and commonly arises in adolescent and young adult populations [34,35]. It is characterized histologically by the production of osteoid by malignant cells and has a variety of histological subtypes, including conventional (osteoblastic, chondroblastic, and fibroblastic types), telangiectatic, small cell, low-grade central, parosteal, periosteal, high-grade surface, and secondary osteosarcoma [3].

The clinical relevance of TAMs in osteosarcoma was first demonstrated by Buddingh et al. [36] (Table 1). Gene profiling analysis of biopsies performed on non-metastatic versus metastatic osteosarcomas revealed a high expression of macrophage-associated genes, such as CD14 and HLA-DR $\alpha$, in non-metastatic tumors, which was expressed by infiltrating hematopoietic cells [36]. The total number of macrophages, which was determined based on the number of $\mathrm{CD} 14^{+}$macrophages, was associated with better survival, but that of the M1-phenotype (CD14/HLA-DR $\alpha$ ) and the M2-phenotype (CD14/CD163) were not correlated with prognosis [36]. A high number of $\mathrm{CD}^{+} 4^{+}$macrophages in prechemotherapy samples were associated with a better response to neoadjuvant chemotherapy, and their numbers increased after chemotherapy [36].

Table 1. Clinicopathological relevance of the infiltration of TAMs in bone sarcomas.

\begin{tabular}{|c|c|c|c|c|c|c|}
\hline $\begin{array}{l}\text { Histological } \\
\text { Subtype }\end{array}$ & $\begin{array}{l}\text { Number of } \\
\text { Patients }\end{array}$ & TAM Markers & TAM Density & $\begin{array}{c}\text { Clinical Significance of } \\
\text { TAMs }\end{array}$ & Year & Reference \\
\hline Osteosarcoma & $\begin{array}{l}53(\text { cohort } 1) \\
88(\text { cohort } 2) \\
20(\text { cohort } 3)\end{array}$ & $\begin{array}{l}\text { Macrophage: CD14 } \\
\text { M1: CD14/HLA-DR } \alpha \\
\text { M2: CD14/CD163 }\end{array}$ & $\begin{array}{l}\text { Mean number of } \\
\text { macrophages: } \\
55 \text { cells per core } \\
\text { (non-metastatic } \\
\text { disease) } \\
27 \text { cells per core } \\
\text { (metastatic disease) }\end{array}$ & $\begin{array}{c}\text { A higher number of CD14 } \\
\text { macrophages was associated } \\
\text { with better overall survival, } \\
\text { vascularity, better response to } \\
\text { chemotherapy. } \\
\text { M1/M2 phenotype: no } \\
\text { correlation with survival } \\
\text { CD14 }{ }^{+} \text {macrophages: } \\
\text { correlated with angiogenesis }\end{array}$ & 2011 & [36] \\
\hline Osteosarcoma & 50 & $\begin{array}{c}\text { Macrophage: CD68 } \\
\text { M1: INOS } \\
\text { M2: CD163 } \\
\text { Others: CD3, CD4, CD8, } \\
\text { CD20, CD117, CD31, } \\
\text { CD146, SMA, OPG }\end{array}$ & $\begin{array}{c}\text { INOS: localized, } 3 \% \text {; } \\
\text { metastatic, } 0 \% \\
\text { CD163: localized, } 1.2 \% \text {; } \\
\text { metastatic, } 0.5 \% \\
\text { CD146: localized, } \\
\text { density score } 3=0 \% \\
\text { metastatic, density } \\
\text { score } 3=7.1 \%\end{array}$ & $\begin{array}{l}\text { Polarized macrophages in } \\
\text { favor of M1 were associated } \\
\text { with non-metastatic process. } \\
\text { INOS and OPG: highly } \\
\text { correlated with each other } \\
\text { CD163 and CD146: highly } \\
\text { correlated with each other }\end{array}$ & 2016 & {$[37]$} \\
\hline Osteosarcoma & 124 & $\begin{array}{c}\text { Macrophage: CD68, } \\
\text { CD163 } \\
\text { M2: CMAF } \\
\text { M1: pSTST1 } \\
\text { Others: CD8, PD-1, } \\
\text { PD-L1 }\end{array}$ & $\begin{array}{l}\text { CD163: } 43.8 \%, \geq 50 \% \\
\text { positive cells } \\
\text { CD68: } 23.4 \%, \geq 50 \% \\
\text { positive cells }\end{array}$ & $\begin{array}{l}\text { A high level of CD163 } \\
\text { macrophages in biopsy } \\
\text { specimens significantly } \\
\text { correlated with a higher } \\
\text { overall survival rate. } \\
\text { CD68 and CD163: highly } \\
\text { correlated }\end{array}$ & 2017 & [38] \\
\hline Osteosarcoma & 247 & $\begin{array}{l}\text { Macrophage: CD68 } \\
\text { M2: CD163 } \\
\text { Checkpoints: CD47 } \\
\text { (tumor), SIRP } \alpha \\
\text { (macrophage) }\end{array}$ & $\begin{array}{c}\text { CD68: } 110 / \mathrm{mm}^{2} \\
\text { (median) } \\
\text { CD163: } 150 / \mathrm{mm}^{2} \\
\text { (median) } \\
\text { CD47: positive in } 53 \% \\
\text { SIRP } \alpha: \text { positive in } 32 \%\end{array}$ & $\begin{array}{l}\text { CD47 (tumor) and SIRP } \alpha \\
\text { (macrophage) expressions } \\
\text { showed weak positive } \\
\text { correlations with both CD68 } \\
\text { and CD163 expressions } \\
\text { across all sarcomas. } \\
\text { A CD47 (tumor) expression } \\
\text { was an adverse prognostic } \\
\text { factor in osteosarcoma. } \\
\text { A lower SIRP } \alpha \text { (macrophage) } \\
\text { score was associated with } \\
\text { worse overall survival in the } \\
\text { non-translocation sarcomas. }\end{array}$ & 2020 & [39] \\
\hline
\end{tabular}


Table 1. Cont.

\begin{tabular}{|c|c|c|c|c|c|c|}
\hline $\begin{array}{l}\text { Histological } \\
\text { Subtype }\end{array}$ & $\begin{array}{l}\text { Number of } \\
\text { Patients }\end{array}$ & TAM Markers & TAM Density & $\begin{array}{c}\text { Clinical Significance of } \\
\text { TAMs }\end{array}$ & Year & Reference \\
\hline Ewing sarcoma & 41 & $\begin{array}{l}\text { Macrophage: CD68, } \\
\text { CD14 }\end{array}$ & $\begin{array}{c}\text { CD68 low } \\
(\leq 30 \text { cells } / \mathrm{HPF}): 51 \% \\
\text { CD68 high } \\
(>30 \text { cells } / \text { HPS }): 49 \%\end{array}$ & $\begin{array}{c}\text { A higher level of CD68 } \\
\text { macrophages was associated } \\
\text { with poorer overall survival } \\
\text { (independent prognostic } \\
\text { factor), enhanced vascularity, } \\
\text { and increase CRP and } \\
\text { WBC counts. }\end{array}$ & 2011 & [40] \\
\hline Ewing sarcoma & 24 & $\begin{array}{l}\text { Macrophage: CD68 } \\
\text { M2: CD163 }\end{array}$ & $\begin{array}{l}\text { Modest to massive } \\
\text { infiltration: } \\
\text { CD68: } 71 \% \\
\text { CD163: } 79 \%\end{array}$ & $\begin{array}{c}\text { A high density of CD163 } \\
\text { macrophages was associated } \\
\text { with localized disease and } \\
\text { longer survival. }\end{array}$ & 2018 & [41] \\
\hline
\end{tabular}

Controversy exists regarding the prognostic significance of the M1/M2-phenotype in osteosarcoma. Dumars et al. compared the expressions of several molecules, including TAM markers, CD146 (vascularity), and osteoprotegerin in localized and metastatic tumors by using immunohistochemistry [37]. A higher infiltration of iNOS ${ }^{+}$M1-like TAMs was observed in localized tumors, whereas a higher vascular density $\left(\mathrm{CD} 146^{+}\right.$cells), which was associated with $\mathrm{CD}_{163}{ }^{+}$M2-like TAMs, was observed in metastatic tumors [37]. Dumars et al. concluded that a dysregulation of M1/M2 polarization in favor of M1-like TAMs is associated with localized osteosarcoma [37]. On the contrary, the correlation between the M2-phenotype and worse prognosis was demonstrated by Gomez-Brouchet et al. [38]. In an immunohistochemical analysis of 124 pretherapeutic biopsies, $43.8 \%$ and $23.4 \%$ had $\mathrm{CD} 63^{+}$and $\mathrm{CD}^{+} 8^{+}$staining greater than $50 \%$ per core, respectively [38]. A high level of CD163 staining was associated with a high expression level of the M2-marker CMAF (macrophage activation factor) but was not related to a high expression level of the M1marker pSTAT1 [38]. In terms of prognostic relevance, a high level of $\mathrm{CD}_{163}{ }^{+}$cells in the biopsies was significantly correlated with a higher overall and metastasis-free survival, whereas a trend for a higher survival was observed in patients with $>50 \% \mathrm{CD} 68^{+}$cells [38].

The clinical significance of CD47 and signal-regulatory protein $\alpha(\operatorname{SIRP} \alpha)$, which are macrophage-related checkpoints, was recently reported. CD47, a transmembrane protein found ubiquitously expressed on normal cells, has increased its expression in a high proportion of malignant tumor cells. This protein acts primarily as a dominant "do not eat me" signal $[42,43]$. If the tumor cells express CD47, it binds to SIRP $\alpha$ on phagocytic immune cells, preventing engulfment [42-44]. Dancsok et al. investigated the expressions of CD68, CD163, CD47, and SIRP $\alpha$ for 1242 sarcomas (24 histological subtypes) by immunohistochemical analysis [39]. Among 247 patients with osteosarcoma, the median numbers of $\mathrm{CD}^{+} 8^{+}$and $\mathrm{CD}_{163^{+}}$macrophage infiltrations were approximately $110 / \mathrm{mm}^{2}$ and $150 / \mathrm{mm}^{2}$, respectively, which were lower than those of angiosarcoma, undifferentiated pleomorphic sarcoma, dedifferentiated liposarcoma, myxofibrosarcoma, pleomorphic liposarcoma, and leiomyosarcoma. CD47 expression was observed in approximately 53\% of osteosarcoma cells, whereas SIRP $\alpha$ expression was identified in approximately $32 \%$ of the infiltrating macrophages [39]. Interestingly, the CD47 and SIRP $\alpha$ expression levels were correlated with higher $\mathrm{CD} 68^{+}$and $\mathrm{CD} 163^{+}$macrophage infiltrates [39]. Although the prognostic relevance of $\mathrm{CD}^{+} 8^{+}$and $\mathrm{CD}_{163^{+}}$macrophage infiltration in osteosarcoma was not described, lower SIRP $\alpha$ levels were associated with a worse overall survival among non-translocation sarcomas, and CD47 expression turned out to be a poor prognostic factor in osteosarcomas [39].

\subsection{Ewing's Sarcoma}

Ewing's sarcoma is the second most frequent bone tumor of childhood and adolescence and is characterized by specific chromosomal translocations that produce FET-ETS fusion oncogenes such as EWS-FLI1 [45]. Despite its unknown mechanisms, increased white blood cell (WBC) counts, elevated C-reactive protein (CRP) concentration, and in- 
creased erythrocyte sedimentation rate (ESR) are frequently observed. These biological characteristics suggest the involvement of TAMs in the initiation and maintenance of Ewing's sarcomas.

A close correlation between tumor-related inflammation and the infiltration of TAMs in the tumor microenvironment was reported by Fujiwara et al. [40] (Table 1). A total of 41 patients with Ewing's sarcoma were divided into two groups according to the density of $\mathrm{CD}^{+} 8^{+}$macrophages: 21 patients (51\%) with lower infiltration ( $\leq 30 \mathrm{CD}^{+}$ cells /HPF) and 20 patients $(49 \%)$ with higher infiltration $\left(>30 \mathrm{CD}^{+} 8^{+}\right.$cells $\left./ \mathrm{HPF}\right)$ [43]. A higher extent of TAM infiltration, greater microvascular density, elevated white blood cell $(\mathrm{WBC})$ counts $(>6800$ cells $/ \mu \mathrm{L})$ and C-reactive protein $(\mathrm{CRP})$ values $(>0.2 \mathrm{mg} / \mathrm{dL})$ were significantly associated with worse prognosis [40]. In addition, higher TAM infiltration was also associated with elevated WBC counts and CRP values, as well as higher microvascular density, and this turned out to be an independently poor prognostic factor [40]. On the other hand, Handl et al. showed no correlation between CD68 ${ }^{+}$macrophage density and clinicopathological parameters [41]. However, the higher number and density of $\mathrm{CD}_{163}{ }^{+}$TAMs were correlated with localized disease but there was a trend toward more prolonged survival in relation to a higher density of CD163 ${ }^{+}$TAMs [41]. In this study, $71 \%$ and $79 \%$ of 24 cases showed a modest to massive infiltration of $\mathrm{CD}^{+} 8^{+}$and $\mathrm{CD} 163^{+}$cells, respectively [41]. Further analyses based on the larger cohorts are necessary to clarify the prognostic role of $\mathrm{CD}^{+} 8^{+}$and $\mathrm{CD}_{163^{+}}$macrophage density in Ewing's sarcoma.

\section{Clinical Relevance of the Infiltration of TAMs in Soft-Tissue Sarcomas}

\subsection{Leiomyosarcoma}

Leiomyosarcoma is a malignant soft-tissue tumor derived from the smooth muscle lineage [46]. It most often develops in the retroperitoneum but can also develop in the extremities [46]. Previous publications have indicated the correlation between the M2-like TAMs or M2-related markers and worse prognosis in leiomyosarcoma (Table 2) [47,48]. Global gene expression profiling by Lee et al. revealed high expressions of several macrophageassociated genes, including CD68 and CD163, which was confirmed by immunohistochemistry [47]. High densities of $\mathrm{CD}^{+} 8^{+}$or $\mathrm{CD} 163^{+}$macrophages were associated with a worse disease-specific survival in non-gynecologic leiomyosarcoma, whereas there was no association in gynecologic leiomyosarcoma [47]. The 5-year disease-specific survival was $<40 \%, 79 \%$, and $100 \%$ in patients with non-gynecologic leiomyosarcomas showing dense, moderate, and sparse $\mathrm{CD}_{163}{ }^{+}$macrophages, respectively [47]. The clinical significance of CSF-1-associated proteins (CD163, CD14, and cathepsin L) was investigated by Ganjoo et al. [48]. The increased levels of CD16 and cathepsin L were both associated with a worse prognosis in gynecologic leiomyosarcoma [48]. In addition, positive staining of all three markers resulted in poor overall survival, which was not confirmed in nongynecologic leiomyosarcoma [48]. These data indicated the pro-tumoral role of TAMs and CSF-1-associated proteins in leiomyosarcoma [48].

\subsection{Myxoid Liposarcoma}

Myxoid liposarcoma, which is the second most common subtype of liposarcoma, occurs predominantly in the extremities of young adults and has a high tendency to metastasize to soft tissue [54]. This tumor is characterized by translocations producing FUS-DDIT3 or, rarely, EWSR1-DDIT3 fusion transcripts $[55,56]$. Correlation between the infiltration of M2-like TAMs and poor prognosis was described by Nabeshima et al. [49] (Table 2). Clinicopathologic evaluation using immunohistochemistry for CD68 and CD163 revealed that a greater infiltration of either $\mathrm{CD}^{+} 8^{+}$macrophages or $\mathrm{CD} 163^{+} \mathrm{M} 2$-like TAMs was associated with decreased overall survival [49]. Interestingly, the macrophage-conditioned medium stimulated cellular motility and invasion by activating the epidermal growth factor receptor (EGFR) with the ligand that was suggested to be an epidermal growth factor (EGF)like growth factor (HB-EGF) [49]. Thus, Nabeshima et al. concluded that TAMs, HB-EGF, and EGFR could be new candidates for therapeutic targets of myxoid liposarcoma [49]. 
Table 2. Clinicopathological relevance of the infiltration of TAMs in soft-tissue sarcomas.

\begin{tabular}{|c|c|c|c|c|c|c|}
\hline $\begin{array}{l}\text { Histological } \\
\text { Subtype }\end{array}$ & $\begin{array}{l}\text { Number of } \\
\text { Patients }\end{array}$ & TAM Markers & TAM Density & $\begin{array}{c}\text { Clinical Significance of } \\
\text { TAMs }\end{array}$ & Year & Reference \\
\hline Leiomyosarcoma & 149 & $\begin{array}{l}\text { Macrophage: CD68, } \\
\text { CD163 }\end{array}$ & $\begin{array}{c}\text { Almost all cases } \\
\text { contained either CD68 } \\
\text { or CD163 }{ }^{+} \text {macrophages. } \\
\text { Non-gynecologic LMS; } \\
\text { CD68: sparse } 31 \% \text {, } \\
\text { moderate } 34 \% \text {, dense } 35 \% \\
\text { CD163: sparse } 10 \% \text {, } \\
\text { moderate } 45 \% \text {, dense } 45 \%\end{array}$ & $\begin{array}{l}\text { Non-gynecologic LMS; } \\
\text { The densities of CD } 68^{+} \text {or } \\
\text { CD163 TAMs were } \\
\text { significantly associated with } \\
\text { disease-specific survival: the } \\
\text { 5-year disease-specific } \\
\text { survivals with the } \\
\text { infiltration of dense, } \\
\text { moderate, and sparse } \\
\text { CD163 TAMs were }<40 \% \text {, } \\
70 \% \text {, and } 100 \% \text {. }\end{array}$ & 2008 & [47] \\
\hline Leiomyosarcoma & 52 & $\begin{array}{c}\text { CSF1 associated } \\
\text { proteins: CD163, CD16, } \\
\text { CTSL }\end{array}$ & $\begin{array}{c}\text { CD163: }<10 \text { cells } / \mathrm{HPF}, \\
6 \% ; \geq 10 \text { cells, } 11 \% ; \\
\geq 20 \text { cells, } 17 \% ; \geq 45 \text { cells, } \\
51 \% ; \text { unknown, } 15 \% \\
\text { CD16: }<10 \text { cells } / \mathrm{HPF}, \\
56 \% ; \geq 10 \text { cells, } 0 \% ; \\
\geq 20 \text { cells, } 13 \% ; \geq 45 \text { cells, } \\
17 \% ; \text { unknown, } 13 \% \\
\text { CTSL: }<10 \text { cells } / \mathrm{HPF}, \\
32 \% ; \geq 10 \text { cells, } 25 \% ; \\
\geq 20 \text { cells, } 4 \% ; \geq 45 \text { cells, } \\
17 \% \text {, unknown, } 23 \%\end{array}$ & $\begin{array}{l}\text { Gynecologic LMS; } \\
\text { The increased immuonstains } \\
\text { of CD16 } \text { CTSL }^{+} \text {, and } \\
\mathrm{CD}^{+} 63^{+} \mathrm{CD}^{+} 6^{+} \mathrm{CTSL}^{+} \text {were } \\
\text { associated with } \\
\text { worse outcome. }\end{array}$ & 2011 & [48] \\
\hline $\begin{array}{l}\text { Myxoid } \\
\text { liposarcoma }\end{array}$ & 78 & $\begin{array}{l}\text { Macrophage: CD68 } \\
\text { M2: CD163 }\end{array}$ & $\begin{array}{c}\text { CD68: high } \\
(\geq 100 / 10 \mathrm{HPF}), 81 \% ; \\
\text { low }(<100 / 10 \mathrm{HPF}), 19 \%\end{array}$ & $\begin{array}{c}\text { Greater CD68 } 8^{+} \text {macrophage } \\
\text { infiltration }(\geq 100 / 10 \mathrm{HPF}) \\
\text { was associated with poorer } \\
\text { overall survival. } \\
\text { Higher levels of CD163 } \\
\text { M2-TAMs were also } \\
\text { associated with poorer } \\
\text { overall survival. }\end{array}$ & 2017 & [49] \\
\hline Synovial sarcoma & 36 & $\begin{array}{l}\text { M2: CD163 } \\
\text { Others: CD4, CD8, } \\
\text { FOXP3, HLA class 1, } \\
\text { PDL1, PDL2 }\end{array}$ & $\begin{array}{l}\text { CD163: observed in all } \\
\text { patients (median, } \\
\left.444 \text { cells } / \mathrm{mm}^{2}\right)\end{array}$ & $\begin{array}{l}\text { An increased infiltration of } \\
\mathrm{CD}^{6} 63^{+} \text {macrophages was } \\
\text { associated with lower } \\
\text { infiltration of CD8 }{ }^{+} \text {and } \\
\text { FOXP3 }^{+} \text {lymphocytes. } \\
\text { A higher infiltration of } \text { CD163 }^{+} \text {macrophages } \\
\text { indicated a significantly } \\
\text { worse overall and } \\
\text { progression-free survival } \\
\text { (negative independent } \\
\text { prognostic factor for overall } \\
\text { survival). }\end{array}$ & 2018 & [50] \\
\hline DFSP & 10 & $\begin{array}{l}\text { M2: CD163, CD206 } \\
\text { Others: periostin, } \\
\text { MMP1, MMP12 }\end{array}$ & $\begin{array}{l}\text { Periostin: positive in all } \\
\text { tumors at the peripheral } \\
\text { area } \\
\text { CD163, CD206: positive } \\
\text { in all tumors } \\
\text { MMP1, MMP12: positive } \\
\text { in the CD163 }{ }^{+} \text {areas }\end{array}$ & $\begin{array}{l}\text { Periostin-MMP1/MMP12 } \\
\text { expression on TAMs in the } \\
\text { peripheral area could be a } \\
\text { possible mechanism of local } \\
\text { aggressiveness of DFSP. }\end{array}$ & 2017 & [51] \\
\hline UPS & 28 & $\begin{array}{l}\text { Macrophage: Iba-1 } \\
\text { M2: CD163, CD204 } \\
\text { Others: CD8 }\end{array}$ & $\begin{array}{l}\text { CD163: } 670 \pm 368 / \mathrm{mm}^{2} \\
\text { CD204: } 479 \pm 390 / \mathrm{mm}^{2}\end{array}$ & $\begin{array}{l}\text { A high density of CD163 } \\
\text { and CD204 } \\
\text { tended to be associated with } \\
\text { poor overall survival rate. }\end{array}$ & 2018 & [52] \\
\hline UPS & 62 & $\begin{array}{l}\text { Macrophage: Iba-1, } \\
\text { CD68 } \\
\text { M2: CD163 }\end{array}$ & $\begin{array}{c}\text { Iba }^{+} \text {TAMs: } 683 / \mathrm{mm}^{2} \\
\text { CD163 }{ }^{+} \text {TAMs: } 406 / \mathrm{mm}^{2} \\
\text { Iba1 }^{+} / \text {CD163 } \\
78 \%\end{array}$ & $\begin{array}{l}\text { A high density of CD163 } \\
\text { TAMs was associated with a } \\
\text { high AJCC stage. } \\
\text { A high percentage of CD163 } \\
\text { TAMs were significantly } \\
\text { associated with a high } \\
\text { FNCLCC grade and } \\
\text { decreased overall survival. }\end{array}$ & 2018 & [53] \\
\hline
\end{tabular}


Table 2. Cont.

\begin{tabular}{|c|c|c|c|c|c|c|}
\hline $\begin{array}{l}\text { Histological } \\
\text { Subtype }\end{array}$ & $\begin{array}{l}\text { Number of } \\
\text { Patients }\end{array}$ & TAM Markers & TAM Density & $\begin{array}{c}\text { Clinical Significance of } \\
\text { TAMs }\end{array}$ & Year & Reference \\
\hline UPS & 67 & $\begin{array}{c}\text { Macrophage: CD68 } \\
\text { M2: CD163 }\end{array}$ & $\begin{array}{l}\text { CD68: } 460 / \mathrm{mm}^{2} \\
\text { (median) } \\
\text { CD163: } 512 / \mathrm{mm}^{2} \\
\text { (median) }\end{array}$ & $\begin{array}{l}\text { Pleomorphic sarcoma types } \\
\text { demonstrated the highest } \\
\text { counts of both CD } 68^{+} \text {and } \\
\text { CD } 163^{+} \text {macrophages, } \\
\text { particularly in UPS. } \\
\text { A higher proportion of } \\
\text { M2-like macrophages than } \\
\text { M1-like macrophages was } \\
\text { observed, particularly } \\
\text { in UPS. }\end{array}$ & 2020 & [39] \\
\hline
\end{tabular}

Abbreviation: CTSL: cathepsin L; DFSP, dermatofibrosarcoma protuberance; UPS, undifferentiated pleomorphic sarcoma.

\subsection{Synovial Sarcoma}

Synovial sarcoma (SS) is a common soft-tissue sarcoma that occurs in adolescents and young adults [57]. This sarcoma is characterized by a specific chromosome translocation that produces the SS18-SSX1/2/4 fusion gene [58]. A correlation between M2-like TAM infiltration and immune cell infiltration in the tumor microenvironment was reported by Oike et al. (Table 2) [50]. In a screening of macrophage-related, lymphocyte-related, and immune checkpoint markers, all tumors $(n=36)$ had $\mathrm{CD}_{163^{+}}$macrophages, whereas $72 \%$, $92 \%$, and $75 \%$ were positive for CD4, CD8, and forkhead box P3 (FOXP3), respectively [50]. Interestingly, there was a correlation between the number of $\mathrm{CD}_{163}{ }^{+}$macrophages and the densities of $\mathrm{CD}^{+}$and $\mathrm{FOXP3}^{+}$lymphocytes [50]. Patients with lower levels of $\mathrm{CD} 163^{+}$ macrophage infiltration, high levels of $\mathrm{CD}^{+}$, and $\mathrm{FOXP}^{+}$lymphocyte infiltration were associated with better overall survival [50]. Regulatory $\mathrm{T}$ cells promote evasion of cancer cells from immune responses and often contribute to worse survival $[59,60]$. Thus, the correlation between a high infiltration of FOXP3 ${ }^{+}$lymphocytes and a better survival outcome in SS was different from the former publications [50]. This inconsistency may be due to their choice of cut-off value and their assumption that $\mathrm{FOXP3}^{+}$lymphocytes that infiltrate into the tumor microenvironment in SS might represent a subset other than regulatory $\mathrm{T}$ cells [50]. FOXP3 ${ }^{+} \mathrm{T}$ cells comprise functionally different subsets, including non-regulatory $\mathrm{T}$ cells. Further studies are needed to determine the role of $\mathrm{FOXP3}^{+}$lymphocytes in SS.

\subsection{Dermatofibrosarcoma Protuberans}

Dermatofibrosarcoma protuberans is a cutaneous fibroblastic tumor that is locally aggressive, with a tendency for local recurrence but rarely metastasizes [61]. Although the prognostic significance of M1/M2-like TAMs were not described, a correlation between M2-like TAMs and the local aggressiveness of this tumor was reported (Table 2) [51]. Immunohistochemical staining revealed CD163, CD206, and periostin, which recruits M2-TAMs in glioblastoma multiforme, and the expressions of these markers have been identified in all studied cases $(n=10)$ at the peripheral areas of the tumors [51]. MMP1 and MMP12, which are modulated by periostin, were also observed in the TAMs-detected area, which may indicate the local aggressiveness of dermatofibrosarcoma protuberans [51].

\subsection{Undifferentiated Pleomorphic Sarcoma}

Undifferentiated pleomorphic sarcoma (UPS), formerly known as malignant fibrous histiocytoma, is one of the most common soft-tissue sarcomas, classified as a subcategory of undifferentiated sarcoma [3]. This tumor is characterized by a high rate of local recurrence (13-42\%) and distant metastasis (31-35\%) due to its infiltrative nature [62]. The infiltration of M2-like TAM is strongly associated with worse outcomes in UPS patients (Table 2) [52]. In a screening of macrophage-related markers by immunohistochemical staining, Komohara et al. reported that the densities of Iba1 ${ }^{+}(\mathrm{M} 1 / \mathrm{M} 2), \mathrm{CD}_{163}{ }^{+}$(M2), and CD204 ${ }^{+}$(M2) TAMs were positively correlated with each other, and that the density of $\mathrm{CD} 163^{+} \mathrm{TAMs}$ was high in older patients or those with a smaller tumor size [52]. In a clinicopathologic analysis 
of 24 patients, there was a trend toward worse survival outcomes in patients with a high density of $\mathrm{CD}_{163}{ }^{+}$or CD204+ ${ }^{+}$TAMs [52]. Shiraishi et al. from the same group validated the correlation between a high percentage of $\mathrm{CD} 163^{+}$TAMs and worse survival outcomes and found a positive correlation with a high tumor grade [53]. Of note, TAM-induced cell proliferation was observed in leiomyosarcoma and myxofibrosarcoma cell lines, and was promoted by IL-6 secreted from TAMs [53].

UPS is known to have increased infiltration of $\mathrm{CD}^{+} 8^{+}$macrophages and CD163 TAMs among the various subtypes of sarcoma [39]. Dancsok et al. reported that pleomorphic types demonstrated the highest counts of both $\mathrm{CD}^{+} 8^{+}$and $\mathrm{CD} 163^{+}$macrophages, particularly in UPS (median CD68 $=460 / \mathrm{mm}^{2}$, CD163 $=512 / \mathrm{mm}^{2}$ ) [39]. Regarding the macrophage polarization, a higher proportion of M2-like macrophages than M1-like macrophages was observed, particularly in UPS (adjusted mean CD163/CD68 = 20.7) and leiomyosarcoma (adjusted mean CD163/CD68 = 17.4) [39]. The prognostic significance of the macrophage polarization in UPS was not described in this paper [39].

\section{Therapeutic Trials Targeting TAMs in Sarcomas}

The identification of the various functions of TAMs has provided unprecedented opportunities for the development of novel therapies for malignant diseases. Accumulating evidence of the pro-tumoral roles of TAMs indicates the antitumor effect of TAMtargeted therapies. Therapeutic strategies directed at TAMs can be classified into four types: (1) limiting macrophage recruitment (e.g., CCL2/C-C motif receptor 2 (CCR2) inhibition),

(2) reprogramming TAMs into antitumor macrophages (e.g., CSF-1/CSF-1R inhibition),

(3) targeting the activation of TAMs (e.g., nucleotide-binding oligomerization domaincontaining protein 2 (NOD2)/NF- $\mathrm{B}$ ), and (4) activation of macrophage phagocytosis (e.g., $\mathrm{CD} 47 / \mathrm{SIRP} \alpha$ inhibition) (Figure 2).

Although several drug interventions have been employed in clinical trials for major types of cancer, trials for bone and soft-tumor sarcomas are limited to date.

Pexidartinib (PLX3397), which is a potent CSF-1/CSF-1R inhibitor, has been tested on sarcomas as part of a clinical trial (NCT01004861, NCT01525602, NCT02390752, and NCT02584647). CSF-1, which is highly expressed in several types of solid tumor, plays a significant role in the recruitment of peripheral blood monocytes to the tumor microenvironment, differentiation into macrophages, and polarization of macrophages toward an M2-like phenotype via binding to CSF-1R, which is a tyrosine kinase receptor that is highly expressed in circulating monocytes and macrophages [11,12,25,63,64]. Preclinical studies have shown that the CSF-1/CSF-1R signaling cascade not only decreases the number of infiltrating TAMs but also repolarizes M2-like to M1-like phenotypes within the tumor microenvironment $[13,65]$. PLX3397 was designed to stabilize CSF-1R in the auto-inhibited state by interacting with the CSF-1R juxtamembrane region, thus resulting in the inactivation of the kinase domain and the prevention of CSF-1 and adenosine triphosphate (ATP) binding [66]. The oral administration of PLX3397 (Turalio ${ }^{\circledR}$ ) has been approved by the U.S. Food and Drug Administration (FDA) for the treatment of unresectable tenosynovial giant cell tumor, which is a rare and locally aggressive non-malignant tumor that overexpresses CSF-1 [67-69]. This drug is currently under investigation with sirolimus in a phase I/II trial for unresectable sarcomas, including Ewing's sarcoma, liposarcoma, leiomyosarcoma, malignant peripheral nerve sheath tumor, synovial sarcoma, and rhabdomyosarcoma (NCT02584647).

Mifamurtide, which is also known as liposomal muramyl tripeptide and muramyl tripeptide phosphatidylethanolamine $\left(\right.$ Mepact $\left.^{\circledR}\right)$, is indicated in children, adolescents, and young adults for the treatment of high-grade, resectable non-metastatic osteosarcoma in the EU [70]. This drug is intravenously administered in conjunction with postoperative multiagent chemotherapy. Mifamurtide stimulates immune responses by binding to NOD2 in an intracellular pattern-recognition receptor molecule expressed mainly in monocytes, macrophages, and dendritic cells [71-73]. Binding to NOD2 results in the activation of the NF-kB pathway, which leads to an increased production of pro-inflammatory 
cytokines, such as TNF-a, IL-1, IL-6, IL-8, interferon gamma (IFN-gamma), and the serum CRP [71,72,74]. Mifamurtide also activates NLR family pyrin domain-containing 3 (NLRP3), which is an essential component of inflammasome, which is a protein complex that promotes the cleavage of procaspase 1 in its active form [72]. Active caspase 1 is essential for the activation of pro-inflammatory cytokines like IL-1 $\beta$. Overall, these pathways in macrophages and monocytes contribute to inflammation, the release of antimicrobial peptides, dendritic cell recruitment, the polarization of T-helper cells, and promotion of bactericidal and potential tumoricidal effects [72]. A phase III randomized clinical trial was conducted by the Children's Oncology Group from 1993 to 1997 [75]. Significant improvements in event-free survival and overall survival were observed in patients who received mifamurtide $[73,75,76]$. However, in the U.S., this drug is an investigational agent, because the FDA refused to approve mifamurtide due to insufficient evidence of a survival advantage [71].

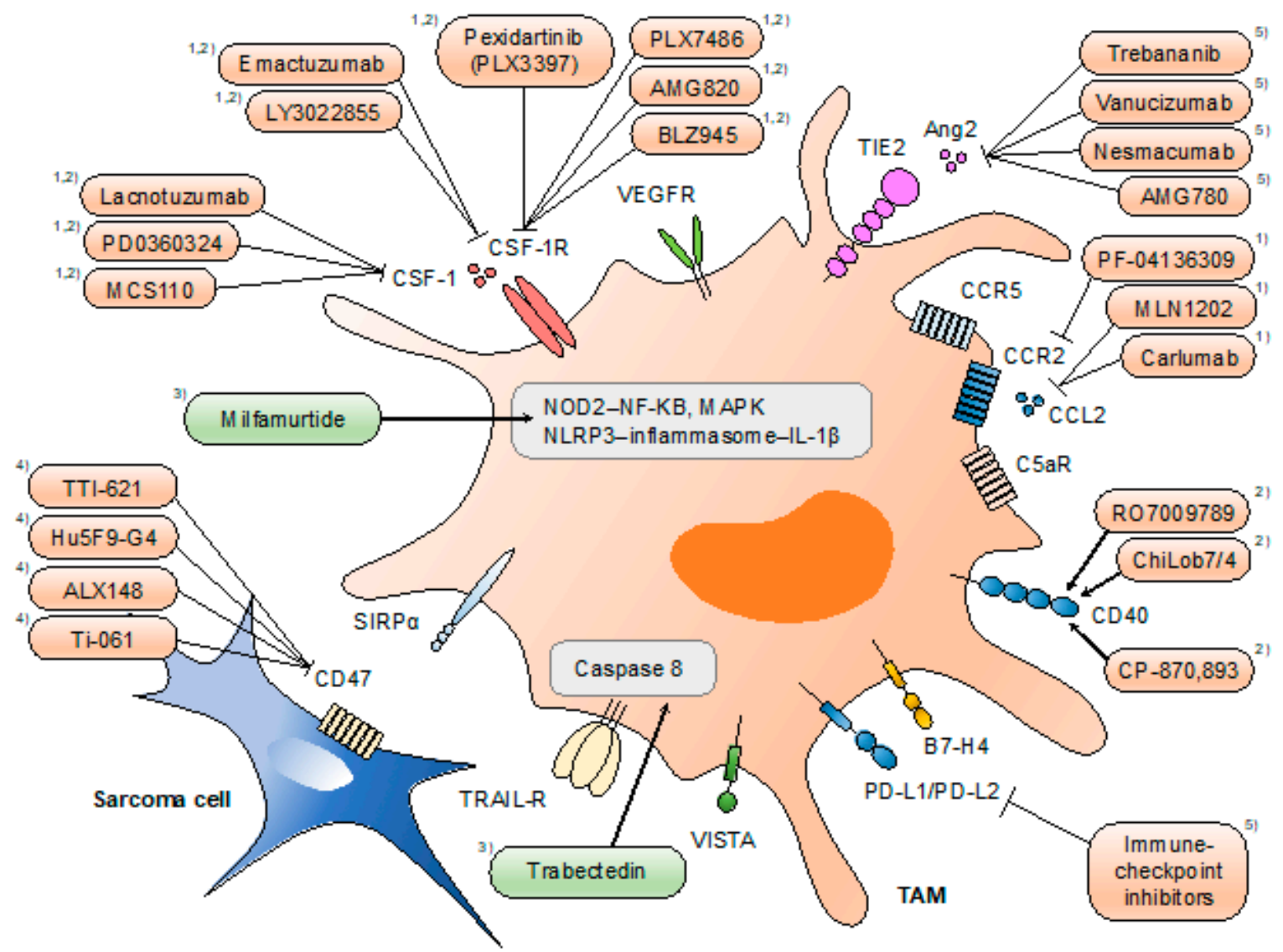

Figure 2. Therapeutic approaches targeting tumor-associated macrophages (TAMs). Strategies directed at TAMs include (1) limiting macrophage recruitment, (2) reprogramming TAMs into antitumor macrophages, (3) targeting the activation of TAMs, (4) activation of macrophage phagocytosis, and (5) others. Drugs highlighted in orange are tested under clinical trials, and those highlighted in green are approved for clinical use (in certain areas). Mifamurtide is indicated in children, adolescents, and young adults for the treatment of high-grade, resectable, non-metastatic osteosarcoma in the EU. Trabectedin partially depletes circulating monocytes and TAMs. Pexidartinib is currently being investigated for single and combined use with sirolimus under clinical phase I/II trials for a variety of histological subtypes of sarcoma.

Trabectedin (Yondelis ${ }^{\circledR}$ ), which was recently approved in the treatment of advanced softtissue sarcomas, was reported to partially deplete circulating monocytes and TAMs [11,77,78]. This was observed in patients with cancer that showed delayed, persistent responses to trabectedin. Trabectedin has been shown to activate a TNF-related apoptosis-inducing ligand (TRAIL)/caspase 8-dependent pathway of apoptosis [11,79]. Of note, monocytes are sensitive to TRAIL, because they express low levels of TRAIL decoy receptors [80]. 
Germano et al. reported that trabectedin reduced TAM density, which was associated with decreased angiogenesis in mouse tumor models and in human sarcoma specimens [78]. These findings raised the issue for an exploitation of the combined use of trabectedin with anti-angiogenic agents and/or immunotherapeutic drugs.

The other candidate targets of TAMs include CCL2/CCR2, CD40, and CD47/SIRP $\alpha$ [11, 12,81]. Regarding the CCL2/CCR2 axis, which plays a role in the recruitment in tumors, phase I and II clinical trials of anti-CCL2 antibodies (carlumab) were performed and completed in solid tumors (NCT00992186) [82] and metastatic prostate cancer (NCT01204996) [83], respectively, which showed no significant antitumor activity as a single agent. The phase I trial of the CCR2 antagonist (PF-04136309) in advanced pancreatic adenocarcinoma (NCT01413022) confirmed its safety and tolerability in an objective tumor response [84]. CD40 is a surface marker of macrophages, which is highly expressed on M1-like TAMs [85]. The combination of a CD40 agonist with gemcitabine effectively circumvented tumormediated immune suppression by promoting antitumor macrophages, which increased the survival rate in patients with surgically incurable pancreatic ductal adenocarcinoma (PDAC) [86]. Several phase I trials of the anti-CD40 agonist have shown tolerability (NCT01433172) $[87,88]$. CD47, an integrin-associated protein that is overexpressed in malignant tumor cells, functions as an inhibitor of macrophage-mediated phagocytosis through the ligation of SIRP $\alpha$ [89]. Several drugs targeting CD47/SIRP $\alpha$ were investigated in several clinical trials. A phase I trial of intratumoral TTI-621, a SIRP $\alpha$-Fc fusion protein, showed tolerability and moderate antitumor efficacy in patients with T cell lymphoma [90]. The intravenous administration of ALX148, which binds to CD47, is under investigation in combination with trastuzumab or pembrolizumab (NCT03013218). The safety and efficacy of these drugs remain to be investigated in patients with sarcoma. The angiopoietin receptor TIE2, a molecule previously known to be restricted to endothelial and hematopoietic stem cells [91,92], is expressed on a subset of TAMs [93]. TIE2 ${ }^{+}$TAMs are closely associated with tumor vasculature and have been found crucial for angiogenesis, which depends on angiopoietin-2 (Ang2), a TIE2 ligand produced by endothelial cells. Several drugs designed to target the Ang2-TIE2 axis, such as trebananib and venucizumab, have been tested for solid tumors [94,95]. Trebananib was combined with paclitaxel, trastuzumab, or bevacizumab, which was tolerable but, so far, its efficacy has been limited in patients with breast cancer [96]. Venucizumab has an acceptable safety and tolerability profile for a heterogeneous group of advanced solid tumors [97], but combined use with mFOLFOX-6 showed limited clinical benefit for metastatic colorectal cancer [98]. The PD-1/PD-L1 axis has been an attractive target in cancer immunotherapy. PD-1 expression on TAMs correlates negatively with phagocytic potency against tumor cells [99], raising a possible effect of the combination of macrophage-targeted therapy and immune checkpoint modulation. A preclinical study demonstrated that the combination of a CSF-1R inhibitor with PD-1 or CTLA4 antagonists elicited tumor regression, while the single use of PD-1 or CTLA4 inhibitors showed limited efficacy [16]. However, a phase I/IIa trial of PLX3397 with pembrolizumab, an anti-PD-1 antibody, for advanced melanoma and other solid tumors was recently terminated for insufficient evidence of clinical efficacy (NCT02452424).

\section{Conclusions and Future Perspectives}

TAMs have important pro- and antitumor functions within the microenvironment of major types of cancers. However, the investigation of the clinical significance of TAMs in bone and soft-tissue sarcomas has been limited. Studies suggest that the infiltration of TAMs is associated with a worse survival outcome in patients with soft-tissue sarcomas, whereas there is no consensus in those with bone sarcomas. This inconsistency may be related to the type of analysis performed, the stage of the tumor, or the use of different macrophage markers. Further study based on a larger cohort with a protocol that reaches consensus is necessary to determine the clinical significance of TAMs in the microenvironment of bone sarcomas. 
Given the association between the increased infiltration of TAMs and worse survival outcomes in most sarcoma subtypes, these cells represent promising targets for novel therapies. TAM-targeted therapeutic approaches have entered the clinical arena. Several types of TAM-targeted therapies, including CSF-1/CSF1-R inhibition, CCL2/CCR2 inhibition, and CD47/SIRP $\alpha$ targeting, have been investigated under clinical trials for major types of cancer. Among these, PLX3397 has been investigated in a single and combined use with sirolimus under clinical trials for a variety of histological subtypes of sarcoma. In preclinical studies, the systemic administration of PLX3397 resulted in the depletion of TAMs and changed the immune cell composition in the microenvironment of major cancer types $[16,100,101]$. In addition, PLX3397 was shown to decrease resistance to chemotherapy and radiotherapy $[25,102,103]$, which indicates a promising antitumor effect for sarcomas that require multidisciplinary treatment.

The presumed hurdle of targeting TAMs could be drug toxicity, since the systemic depletion of macrophages may lead to increased infections or impaired tissue-resident macrophages [104]. In a phase II trial of PLX3397 for tenosynovial giant cell tumor, treatment-emergent adverse events resulted in permanent treatment discontinuation in 13\% of PLX3397 recipients, in whom most of these adverse events were hepatotoxicity $[68,105]$. These findings underscore the necessity for the development of a novel approach that reduces the toxicity of TAM-targeted drugs. The recent development of nanomedicine strategies targeting TAMs are encouraging [106-108] and are key to overcoming the toxicity associated with the TAM-targeted therapeutics.

Author Contributions: Writing-original draft preparation, T.F. (Tomohiro Fujiwara); resources, J.H.; writing-review, K.O., A.Y., H.K., T.H., M.K., H.T., E.N., T.K., T.F. (Toshiyoshi Fujiwara), and T.O. All authors have read and agreed to the published version of the manuscript.

Funding: This study was supported by a grant-in-aid for overseas research fellowships from the Yasuda Medical Foundation (2018; T.F. (Tomohiro Fujiwara)), JSPS KAKENHI Grant Number 19H03784, and a grant-in-aid for overseas research fellowships from the Japan Society for the Promotion of Science (201860336; T.F. (Tomohiro Fujiwara)).

Data Availability Statement: Not applicable.

Conflicts of Interest: The authors declare no potential conflict of interest.

\section{References}

1. Clark, M.A.; Fisher, C.; Judson, I.; Thomas, J.M. Soft-tissue sarcomas in adults. N. Engl. J. Med. 2005, 353, 701-711. [CrossRef] [PubMed]

2. Dorfman, H.D.; Czerniak, B. Bone cancers. Cancer 1995, 75, 203-210. [CrossRef]

3. WHO_Classification_of_Tumours_Editorial_Board. WHO Classification of Tumours of Soft Tissue and Bone, 5th ed.; International Agency for Research on Cancer, World Health Organization: Lyon, France, 2020.

4. Allison, D.C.; Carney, S.C.; Ahlmann, E.R.; Hendifar, A.; Chawla, S.; Fedenko, A.; Angeles, C.; Menendez, L.R. A meta-analysis of osteosarcoma outcomes in the modern medical era. Sarcoma 2012, 2012, 704872. [CrossRef] [PubMed]

5. Eilber, F.; Giuliano, A.; Eckardt, J.; Patterson, K.; Moseley, S.; Goodnight, J. Adjuvant chemotherapy for osteosarcoma: A randomized prospective trial. J. Clin. Oncol. 1987, 5, 21-26. [CrossRef] [PubMed]

6. Ferrari, S.; Smeland, S.; Mercuri, M.; Bertoni, F.; Longhi, A.; Ruggieri, P.; Alvegard, T.A.; Picci, P.; Capanna, R.; Bernini, G.; et al. Neoadjuvant chemotherapy with high-dose Ifosfamide, high-dose methotrexate, cisplatin, and doxorubicin for patients with localized osteosarcoma of the extremity: A joint study by the Italian and Scandinavian Sarcoma Groups. J. Clin. Oncol. Off. J. Am. Soc. Clin. Oncol. 2005, 23, 8845-8852. [CrossRef]

7. Tawbi, H.A.; Burgess, M.; Bolejack, V.; Van Tine, B.A.; Schuetze, S.M.; Hu, J.; D’Angelo, S.; Attia, S.; Riedel, R.F.; Priebat, D.A.; et al. Pembrolizumab in advanced soft-tissue sarcoma and bone sarcoma (SARC028): A multicentre, two-cohort, single-arm, open-label, phase 2 trial. Lancet Oncol. 2017, 18, 1493-1501. [CrossRef]

8. D'Angelo, S.P.; Mahoney, M.R.; Van Tine, B.A.; Atkins, J.; Milhem, M.M.; Jahagirdar, B.N.; Antonescu, C.R.; Horvath, E.; Tap, W.D.; Schwartz, G.K. Nivolumab with or without ipilimumab treatment for metastatic sarcoma (Alliance A091401): Two open-label, non-comparative, randomised, phase 2 trials. Lancet Oncol. 2018, 19, 416-426. [CrossRef]

9. Le Cesne, A.; Marec-Berard, P.; Blay, J.-Y.; Gaspar, N.; Bertucci, F.; Penel, N.; Bompas, E.; Cousin, S.; Toulmonde, M.; Bessede, A. Programmed cell death 1 (PD-1) targeting in patients with advanced osteosarcomas: Results from the PEMBROSARC study. Eur. J. Cancer 2019, 119, 151-157. [CrossRef]

10. Noy, R.; Pollard, J.W. Tumor-associated macrophages: From mechanisms to therapy. Immunity 2014, 41, 49-61. [CrossRef] 
11. Mantovani, A.; Marchesi, F.; Malesci, A.; Laghi, L.; Allavena, P. Tumour-associated macrophages as treatment targets in oncology. Nat. Rev. Clin. Oncol. 2017, 14, 399-416. [CrossRef]

12. Yang, L.; Zhang, Y. Tumor-associated macrophages: From basic research to clinical application. J. Hematol. Oncol. 2017, 10, 58. [CrossRef]

13. Pyonteck, S.M.; Akkari, L.; Schuhmacher, A.J.; Bowman, R.L.; Sevenich, L.; Quail, D.F.; Olson, O.C.; Quick, M.L.; Huse, J.T.; Teijeiro, V.; et al. CSF-1R inhibition alters macrophage polarization and blocks glioma progression. Nat. Med. 2013, 19, 1264-1272. [CrossRef]

14. Xu, J.; Escamilla, J.; Mok, S.; David, J.; Priceman, S.; West, B.; Bollag, G.; McBride, W.; Wu, L. CSF1R signaling blockade stanches tumor-infiltrating myeloid cells and improves the efficacy of radiotherapy in prostate cancer. Cancer Res. 2013, 73, 2782-2794. [CrossRef] [PubMed]

15. Ries, C.H.; Cannarile, M.A.; Hoves, S.; Benz, J.; Wartha, K.; Runza, V.; Rey-Giraud, F.; Pradel, L.P.; Feuerhake, F.; Klaman, I. Targeting tumor-associated macrophages with anti-CSF-1R antibody reveals a strategy for cancer therapy. Cancer Cell 2014, 25, 846-859. [CrossRef]

16. Zhu, Y.; Knolhoff, B.L.; Meyer, M.A.; Nywening, T.M.; West, B.L.; Luo, J.; Wang-Gillam, A.; Goedegebuure, S.P.; Linehan, D.C.; DeNardo, D.G. CSF1/CSF1R blockade reprograms tumor-infiltrating macrophages and improves response to T-cell checkpoint immunotherapy in pancreatic cancer models. Cancer Res. 2014, 74, 5057-5069. [CrossRef]

17. Butowski, N.; Colman, H.; De Groot, J.F.; Omuro, A.M.; Nayak, L.; Wen, P.Y.; Cloughesy, T.F.; Marimuthu, A.; Haidar, S.; Perry, A. Orally administered colony stimulating factor 1 receptor inhibitor PLX3397 in recurrent glioblastoma: An Ivy Foundation Early Phase Clinical Trials Consortium phase II study. Neuro Oncol. 2015, 18, 557-564. [CrossRef] [PubMed]

18. Arakaki, R.; Yamasaki, T.; Kanno, T.; Shibasaki, N.; Sakamoto, H.; Utsunomiya, N.; Sumiyoshi, T.; Shibuya, S.; Tsuruyama, T.; Nakamura, E. CCL 2 as a potential therapeutic target for clear cell renal cell carcinoma. Cancer Med. 2016, 5, 2920-2933. [CrossRef]

19. Yan, D.; Kowal, J.; Akkari, L.; Schuhmacher, A.J.; Huse, J.T.; West, B.L.; Joyce, J.A. Inhibition of colony stimulating factor-1 receptor abrogates microenvironment-mediated therapeutic resistance in gliomas. Oncogene 2017, 36, 6049-6058. [CrossRef] [PubMed]

20. Zhou, Q.; Xian, M.; Xiang, S.; Xiang, D.; Shao, X.; Wang, J.; Cao, J.; Yang, X.; Yang, B.; Ying, M. All-trans retinoic acid prevents osteosarcoma metastasis by inhibiting M2 polarization of tumor-associated macrophages. Cancer Immunol. Res. 2017, 5, 547-559. [CrossRef] [PubMed]

21. Malfitano, A.M.; Pisanti, S.; Napolitano, F.; Di Somma, S.; Martinelli, R.; Portella, G. Tumor-associated macrophage status in cancer treatment. Cancers 2020, 12, 1987. [CrossRef]

22. Greten, F.R.; Karin, M. The IKK/NF- $\mathrm{KB}$ activation pathway-a target for prevention and treatment of cancer. Cancer Lett. 2004, 206, 193-199. [CrossRef] [PubMed]

23. Kong, L.; Zhou, Y.; Bu, H.; Lv, T.; Shi, Y.; Yang, J. Deletion of interleukin-6 in monocytes/macrophages suppresses the initiation of hepatocellular carcinoma in mice. J. Exp. Clin. Cancer Res. 2016, 35, 131. [CrossRef] [PubMed]

24. Grivennikov, S.I.; Wang, K.; Mucida, D.; Stewart, C.A.; Schnabl, B.; Jauch, D.; Taniguchi, K.; Yu, G.-Y.; Österreicher, C.H.; Hung, K.E. Adenoma-linked barrier defects and microbial products drive IL-23/IL-17-mediated tumour growth. Nature 2012, 491, 254-258. [CrossRef] [PubMed]

25. Ruffell, B.; Coussens, L.M. Macrophages and therapeutic resistance in cancer. Cancer Cell 2015, 27, 462-472. [CrossRef]

26. Finkernagel, F.; Reinartz, S.; Lieber, S.; Adhikary, T.; Wortmann, A.; Hoffmann, N.; Bieringer, T.; Nist, A.; Stiewe, T.; Jansen, J.M. The transcriptional signature of human ovarian carcinoma macrophages is associated with extracellular matrix reorganization. Oncotarget 2016, 7, 75339. [CrossRef] [PubMed]

27. Qian, B.-Z.; Pollard, J.W. Macrophage diversity enhances tumor progression and metastasis. Cell 2010, 141, 39-51. [CrossRef]

28. Ruffell, B.; Affara, N.I.; Coussens, L.M. Differential macrophage programming in the tumor microenvironment. Trends Immunol. 2012, 33, 119-126. [CrossRef]

29. Kryczek, I.; Wei, S.; Zou, L.; Zhu, G.; Mottram, P.; Xu, H.; Chen, L.; Zou, W. Cutting edge: Induction of B7-H4 on APCs through IL-10: Novel suppressive mode for regulatory T cells. J. Immunol. 2006, 177, 40-44. [CrossRef]

30. Wang, L.; Rubinstein, R.; Lines, J.L.; Wasiuk, A.; Ahonen, C.; Guo, Y.; Lu, L.-F.; Gondek, D.; Wang, Y.; Fava, R.A. VISTA, a novel mouse Ig superfamily ligand that negatively regulates T cell responses. J. Exp. Med. 2011, 208, 577-592. [CrossRef] [PubMed]

31. Jung, K.Y.; Cho, S.W.; Kim, Y.A.; Kim, D.; Oh, B.-C.; Park, D.J.; Park, Y.J. Cancers with higher density of tumor-associated macrophages were associated with poor survival rates. J. Pathol. Transl. Med. 2015, 49, 318. [CrossRef]

32. Zhang, Q.-W.; Liu, L.; Gong, C.-Y.; Shi, H.-S.; Zeng, Y.-H.; Wang, X.-Z.; Zhao, Y.-W.; Wei, Y.-Q. Prognostic significance of tumor-associated macrophages in solid tumor: A meta-analysis of the literature. PLoS ONE 2012, 7, e50946.

33. Ni, C.; Yang, L.; Xu, Q.; Yuan, H.; Wang, W.; Xia, W.; Gong, D.; Zhang, W.; Yu, K. CD68- and CD163-positive tumor infiltrating macrophages in non-metastatic breast cancer: A retrospective study and meta-analysis. J. Cancer 2019, 10, 4463-4472. [CrossRef]

34. Ritter, J.; Bielack, S.S. Osteosarcoma. Ann. Oncol. Off. J. Eur. Soc. Med Oncol./ESMO 2010, 21, vii320-vii325. [CrossRef]

35. Whelan, J.S.; Davis, L.E. Osteosarcoma, chondrosarcoma, and chordoma. J. Clin. Oncol. 2018, 36, 188-193. [CrossRef] [PubMed]

36. Buddingh, E.P.; Kuijjer, M.L.; Duim, R.A.; Burger, H.; Agelopoulos, K.; Myklebost, O.; Serra, M.; Mertens, F.; Hogendoorn, P.C.; Lankester, A.C.; et al. Tumor-infiltrating macrophages are associated with metastasis suppression in high-grade osteosarcoma: A rationale for treatment with macrophage activating agents. Clin. Cancer Res. Off. J. Am. Assoc. Cancer Res. 2011, 17, $2110-2119$. [CrossRef] 
37. Dumars, C.; Ngyuen, J.-M.; Gaultier, A.; Lanel, R.; Corradini, N.; Gouin, F.; Heymann, D.; Heymann, M.-F. Dysregulation of macrophage polarization is associated with the metastatic process in osteosarcoma. Oncotarget 2016, 7, 78343. [CrossRef]

38. Gomez-Brouchet, A.; Illac, C.; Gilhodes, J.; Bouvier, C.; Aubert, S.; Guinebretiere, J.M.; Marie, B.; Larousserie, F.; Entz-Werle, N.; de Pinieux, G.; et al. CD163-positive tumor-associated macrophages and CD8-positive cytotoxic lymphocytes are powerful diagnostic markers for the therapeutic stratification of osteosarcoma patients: An immunohistochemical analysis of the biopsies fromthe French OS2006 phase 3 trial. Oncoimmunology 2017, 6, e1331193. [CrossRef] [PubMed]

39. Dancsok, A.R.; Gao, D.; Lee, A.F.; Steigen, S.E.; Blay, J.Y.; Thomas, D.M.; Maki, R.G.; Nielsen, T.O.; Demicco, E.G. Tumor-associated macrophages and macrophage-related immune checkpoint expression in sarcomas. Oncoimmunology 2020, 9, 1747340. [CrossRef]

40. Fujiwara, T.; Fukushi, J.; Yamamoto, S.; Matsumoto, Y.; Setsu, N.; Oda, Y.; Yamada, H.; Okada, S.; Watari, K.; Ono, M.; et al. Macrophage infiltration predicts a poor prognosis for human ewing sarcoma. Am J Pathol 2011, 179, 1157-1170. [CrossRef]

41. Handl, M.; Hermanova, M.; Hotarkova, S.; Jarkovsky, J.; Mudry, P.; Shatokhina, T.; Vesela, M.; Sterba, J.; Zambo, I. Clinicopathological correlation of tumor-associated macrophages in Ewing sarcoma. Biomed. Pap. Med. Fac. Univ. Palacky Olomouc. Czech Repub. 2018, 162, 54-60. [CrossRef]

42. Chao, M.P.; Weissman, I.L.; Majeti, R. The CD47-SIRP $\alpha$ pathway in cancer immune evasion and potential therapeutic implications. Curr. Opin. Immunol. 2012, 24, 225-232. [CrossRef]

43. McCracken, M.N.; Cha, A.C.; Weissman, I.L. Molecular Pathways: Activating T Cells after Cancer Cell Phagocytosis from Blockade of CD47 "Don't Eat Me" Signals. Clin. Cancer Res. Off. J. Am. Assoc. Cancer Res. 2015, 21, 3597-3601. [CrossRef] [PubMed]

44. Zhao, X.W.; van Beek, E.M.; Schornagel, K.; Van der Maaden, H.; Van Houdt, M.; Otten, M.A.; Finetti, P.; Van Egmond, M.; Matozaki, T.; Kraal, G. CD47-signal regulatory protein- $\alpha(\mathrm{SIRP} \alpha)$ interactions form a barrier for antibody-mediated tumor cell destruction. Proc. Natl. Acad. Sci. USA 2011, 108, 18342-18347. [CrossRef]

45. Grünewald, T.G.; Cidre-Aranaz, F.; Surdez, D.; Tomazou, E.M.; de Álava, E.; Kovar, H.; Sorensen, P.H.; Delattre, O.; Dirksen, U. Ewing sarcoma. Nat. Rev. Dis. Primers 2018, 4, 1-22. [CrossRef]

46. Serrano, C.; George, S. Leiomyosarcoma. Hematol. Oncol. Clin. North Am. 2013, 27, 957. [CrossRef]

47. Lee, C.H.; Espinosa, I.; Vrijaldenhoven, S.; Subramanian, S.; Montgomery, K.D.; Zhu, S.; Marinelli, R.J.; Peterse, J.L.; Poulin, N.; Nielsen, T.O.; et al. Prognostic significance of macrophage infiltration in leiomyosarcomas. Clin. Cancer Res. Off. J. Am. Assoc. Cancer Res. 2008, 14, 1423-1430. [CrossRef]

48. Ganjoo, K.N.; Witten, D.; Patel, M.; Espinosa, I.; La, T.; Tibshirani, R.; van de Rijn, M.; Jacobs, C.; West, R.B. The prognostic value of tumor-associated macrophages in leiomyosarcoma: A single institution study. Am. J. Clin. Oncol. 2011, 34, 82. [CrossRef] [PubMed]

49. Nabeshima, A.; Matsumoto, Y.; Fukushi, J.; Iura, K.; Matsunobu, T.; Endo, M.; Fujiwara, T.; Iida, K.; Fujiwara, Y.; Hatano, M.; et al. Tumour-associated macrophages correlate with poor prognosis in myxoid liposarcoma and promote cell motility and invasion via the HB-EGF-EGFR-PI3K/Akt pathways. Br. J. Cancer 2015, 112, 547-555. [CrossRef]

50. Oike, N.; Kawashima, H.; Ogose, A.; Hotta, T.; Hatano, H.; Ariizumi, T.; Sasaki, T.; Yamagishi, T.; Umezu, H.; Endo, N. Prognostic impact of the tumor immune microenvironment in synovial sarcoma. Cancer Sci. 2018, 109, 3043-3054. [CrossRef]

51. Fujimura, T.; Kakizaki, A.; Sato, Y.; Tanita, K.; Furudate, S.; Aiba, S. The Immunological Roles of Periostin/Tumor-Associated Macrophage Axis in Development of Dermatofibrosarcoma Protuberans. Anticancer Res. 2017, 37, 2867-2873. [CrossRef] [PubMed]

52. Komohara, Y.; Takeya, H.; Wakigami, N.; Kusada, N.; Bekki, H.; Ishihara, S.; Takeya, M.; Nakashima, Y.; Oda, Y. Positive correlation between the density of macrophages and T-cells in undifferentiated sarcoma. Med. Mol. Morphol. 2019, 52, 44-51. [CrossRef] [PubMed]

53. Shiraishi, D.; Fujiwara, Y.; Horlad, H.; Saito, Y.; Iriki, T.; Tsuboki, J.; Cheng, P.; Nakagata, N.; Mizuta, H.; Bekki, H.; et al. CD163 Is Required for Protumoral Activation of Macrophages in Human and Murine Sarcoma. Cancer Res. 2018, 78, 3255-3266. [CrossRef] [PubMed]

54. Spillane, A.J.; Fisher, C.; Thomas, J.M. Myxoid liposarcoma-frequency and the natural history of nonpulmonary soft tissue metastases. Ann. Surg. Oncol. 1999, 6, 389-394. [CrossRef] [PubMed]

55. Bode-Lesniewska, B.; Frigerio, S.; Exner, U.; Abdou, M.; Moch, H.; Zimmermann, D. Relevance of translocation type in myxoid liposarcoma and identification of a novel EWSR1-DDIT3 fusion. GenesChromosomes Cancer 2007, 46, 961-971. [CrossRef] [PubMed]

56. Göransson, M.; Andersson, M.K.; Forni, C.; Ståhlberg, A.; Andersson, C.; Olofsson, A.; Mantovani, R.; Åman, P. The myxoid liposarcoma FUS-DDIT3 fusion oncoprotein deregulates NF-kB target genes by interaction with NFKBIZ. Oncogene 2009, 28, 270-278. [CrossRef] [PubMed]

57. Ferrari, A.; Bisogno, G.; Alaggio, R.; Cecchetto, G.; Collini, P.; Rosolen, A.; Meazza, C.; Indolfi, P.; Garaventa, A.; De Sio, L. Synovial sarcoma of children and adolescents: The prognostic role of axial sites. Eur. J. Cancer 2008, 44, 1202-1209. [CrossRef] [PubMed]

58. Stacchiotti, S.; Van Tine, B.A. Synovial sarcoma: Current concepts and future perspectives. J. Clin. Oncol. 2018, 36, 180-187. [CrossRef]

59. Sakaguchi, S. Naturally arising Foxp3-expressing CD25+CD4+ regulatory T cells in immunological tolerance to self and non-self. Nat. Immunol. 2005, 6, 345-352. [CrossRef] 
60. Wolf, D.; Wolf, A.M.; Rumpold, H.; Fiegl, H.; Zeimet, A.G.; Muller-Holzner, E.; Deibl, M.; Gastl, G.; Gunsilius, E.; Marth, C. The expression of the regulatory $\mathrm{T}$ cell-specific forkhead box transcription factor FoxP3 is associated with poor prognosis in ovarian cancer. Clin. Cancer Res. 2005, 11, 8326-8331. [CrossRef]

61. Saiag, P.; Grob, J.-J.; Lebbe, C.; Malvehy, J.; Del Marmol, V.; Pehamberger, H.; Peris, K.; Stratigos, A.; Middelton, M.; Basholt, L. Diagnosis and treatment of dermatofibrosarcoma protuberans. European consensus-based interdisciplinary guideline. Eur. J. Cancer 2015, 51, 2604-2608. [CrossRef]

62. Chen, S.; Huang, W.; Luo, P.; Cai, W.; Yang, L.; Sun, Z.; Zheng, B.; Yan, W.; Wang, C. Undifferentiated pleomorphic sarcoma: Long-term follow-up from a large institution. Cancer Manag. Res. 2019, 11, 10001. [CrossRef]

63. Gonzalez, H.; Hagerling, C.; Werb, Z. Roles of the immune system in cancer: From tumor initiation to metastatic progression. Genes Dev. 2018, 32, 1267-1284. [CrossRef]

64. Tamura, R.; Tanaka, T.; Yamamoto, Y.; Akasaki, Y.; Sasaki, H. Dual role of macrophage in tumor immunity. Immunotherapy 2018, 10, 899-909. [CrossRef] [PubMed]

65. Peyraud, F.; Cousin, S.; Italiano, A. CSF-1R Inhibitor Development: Current Clinical Status. Curr. Oncol. Rep. 2017, 19, 70. [CrossRef]

66. Benner, B.; Good, L.; Quiroga, D.; Schultz, T.E.; Kassem, M.; Carson, W.E.; Cherian, M.A.; Sardesai, S.; Wesolowski, R. Pexidartinib, a Novel Small Molecule CSF-1R Inhibitor in Use for Tenosynovial Giant Cell Tumor: A Systematic Review of Pre-Clinical and Clinical Development. Drug Des. Deve. 2020, 14, 1693-1704. [CrossRef] [PubMed]

67. Giustini, N.; Bernthal, N.M.; Bukata, S.V.; Singh, A.S. Tenosynovial giant cell tumor: Case report of a patient effectively treated with pexidartinib (PLX3397) and review of the literature. Clin. Sarcoma Res. 2018, 8, 14. [CrossRef] [PubMed]

68. Lamb, Y.N. Pexidartinib: First Approval. Drugs 2019, 79, 1805-1812. [CrossRef]

69. Tap, W.D.; Wainberg, Z.A.; Anthony, S.P.; Ibrahim, P.N.; Zhang, C.; Healey, J.H.; Chmielowski, B.; Staddon, A.P.; Cohn, A.L.; Shapiro, G.I.; et al. Structure-Guided Blockade of CSF1R Kinase in Tenosynovial Giant-Cell Tumor. N. Engl. J. Med. 2015, 373, 428-437. [CrossRef]

70. Frampton, J.E. Mifamurtide. Pediatric Drugs 2010, 12, 141-153. [CrossRef] [PubMed]

71. Jimmy, R.; Stern, C.; Lisy, K.; White, S. Effectiveness of mifamurtide in addition to standard chemotherapy for high-grade osteosarcoma: A systematic review. Jbi Database Syst. Rev. Implement. Rep. 2017, 15, 2113-2152. [CrossRef]

72. Kager, L.; Pötschger, U.; Bielack, S. Review of mifamurtide in the treatment of patients with osteosarcoma. Ther. Clin. Risk Manag. 2010, 6, 279. [CrossRef]

73. Nardin, A.; Lefebvre, M.; Labroquere, K.; Faure, O.; Abastado, J. Liposomal muramyl tripeptide phosphatidylethanolamine: Targeting and activating macrophages for adjuvant treatment of osteosarcoma. Curr. Cancer Drug Targets 2006, 6, 123-133. [CrossRef] [PubMed]

74. Asano, T.; Kleinerman, E.S. Liposome-encapsulated MTP-PE: A novel biologic agent for cancer therapy. J. Immunother. Emphas. Tumor Immunol. Off. J. Soc. Biol. Ther. 1993, 14, 286-292. [CrossRef] [PubMed]

75. Meyers, P.A.; Schwartz, C.L.; Krailo, M.D.; Healey, J.H.; Bernstein, M.L.; Betcher, D.; Ferguson, W.S.; Gebhardt, M.C.; Goorin, A.M.; Harris, M.; et al. Osteosarcoma: The addition of muramyl tripeptide to chemotherapy improves overall survival-A report from the Children's Oncology Group. J. Clin. Oncol. Off. J. Am. Soc. Clin. Oncol. 2008, 26, 633-638. [CrossRef] [PubMed]

76. Provisor, A.J.; Ettinger, L.J.; Nachman, J.B.; Krailo, M.D.; Makley, J.T.; Yunis, E.J.; Huvos, A.G.; Betcher, D.L.; Baum, E.S.; Kisker, C.T. Treatment of nonmetastatic osteosarcoma of the extremity with preoperative and postoperative chemotherapy: A report from the Children's Cancer Group. J. Clin. Oncol. 1997, 15, 76-84. [CrossRef] [PubMed]

77. DeNardo, D.G.; Brennan, D.J.; Rexhepaj, E.; Ruffell, B.; Shiao, S.L.; Madden, S.F.; Gallagher, W.M.; Wadhwani, N.; Keil, S.D.; Junaid, S.A. Leukocyte complexity predicts breast cancer survival and functionally regulates response to chemotherapy. Cancer Discov. 2011, 1, 54-67. [CrossRef] [PubMed]

78. Germano, G.; Frapolli, R.; Simone, M.; Tavecchio, M.; Erba, E.; Pesce, S.; Pasqualini, F.; Grosso, F.; Sanfilippo, R.; Casali, P.G. Antitumor and anti-inflammatory effects of trabectedin on human myxoid liposarcoma cells. Cancer Res. 2010, 70, $2235-2244$. [CrossRef] [PubMed]

79. Germano, G.; Frapolli, R.; Belgiovine, C.; Anselmo, A.; Pesce, S.; Liguori, M.; Erba, E.; Uboldi, S.; Zucchetti, M.; Pasqualini, F. Role of macrophage targeting in the antitumor activity of trabectedin. Cancer Cell 2013, 23, 249-262. [CrossRef]

80. Liguori, M.; Buracchi, C.; Pasqualini, F.; Bergomas, F.; Pesce, S.; Sironi, M.; Grizzi, F.; Mantovani, A.; Belgiovine, C.; Allavena, P. Functional TRAIL receptors in monocytes and tumor-associated macrophages: A possible targeting pathway in the tumor microenvironment. Oncotarget 2016, 7, 41662. [CrossRef]

81. Qiu, S.Q.; Waaijer, S.J.H.; Zwager, M.C.; de Vries, E.G.E.; van der Vegt, B.; Schroder, C.P. Tumor-associated macrophages in breast cancer: Innocent bystander or important player? Cancer Treat Rev. 2018, 70, 178-189. [CrossRef] [PubMed]

82. Pienta, K.J.; Machiels, J.-P.; Schrijvers, D.; Alekseev, B.; Shkolnik, M.; Crabb, S.J.; Li, S.; Seetharam, S.; Puchalski, T.A.; Takimoto, C. Phase 2 study of carlumab (CNTO 888), a human monoclonal antibody against CC-chemokine ligand 2 (CCL2), in metastatic castration-resistant prostate cancer. Investig. New Drugs 2013, 31, 760-768. [CrossRef]

83. Sandhu, S.K.; Papadopoulos, K.; Fong, P.C.; Patnaik, A.; Messiou, C.; Olmos, D.; Wang, G.; Tromp, B.J.; Puchalski, T.A.; Balkwill, F. A first-in-human, first-in-class, phase I study of carlumab (CNTO 888), a human monoclonal antibody against CC-chemokine ligand 2 in patients with solid tumors. Cancer Chemother. Pharmacol. 2013, 71, 1041-1050. [CrossRef] [PubMed] 
84. Sanford, D.E.; Belt, B.A.; Panni, R.Z.; Mayer, A.; Deshpande, A.D.; Carpenter, D.; Mitchem, J.B.; Plambeck-Suess, S.M.; Worley, L.A.; Goetz, B.D. Inflammatory monocyte mobilization decreases patient survival in pancreatic cancer: A role for targeting the CCL2/CCR2 axis. Clin. Cancer Res. 2013, 19, 3404-3415. [CrossRef] [PubMed]

85. Vonderheide, R.H.; Bajor, D.L.; Winograd, R.; Evans, R.A.; Bayne, L.J.; Beatty, G.L. CD40 immunotherapy for pancreatic cancer. Cancer Immunol. Immunother. 2013, 62, 949-954. [CrossRef]

86. Beatty, G.L.; Chiorean, E.G.; Fishman, M.P.; Saboury, B.; Teitelbaum, U.R.; Sun, W.; Huhn, R.D.; Song, W.; Li, D.; Sharp, L.L. CD40 agonists alter tumor stroma and show efficacy against pancreatic carcinoma in mice and humans. Science 2011, 331, 1612-1616. [CrossRef]

87. Rüter, J.; Antonia, S.J.; Burris, H.A.; Huhn, R.D.; Vonderheide, R.H. Immune modulation with weekly dosing of an agonist CD40 antibody in a phase I study of patients with advanced solid tumors. Cancer Biol. Ther. 2010, 10, 983-993. [CrossRef]

88. Vonderheide, R.H.; Flaherty, K.T.; Khalil, M.; Stumacher, M.S.; Bajor, D.L.; Hutnick, N.A.; Sullivan, P.; Mahany, J.J.; Gallagher, M.; Kramer, A. Clinical activity and immune modulation in cancer patients treated with CP-870,893, a novel CD40 agonist monoclonal antibody. J. Clin. Oncol. 2007, 25, 876-883. [CrossRef]

89. Takizawa, H.; Manz, M.G. Macrophage tolerance: CD47-SIRP- $\alpha$-mediated signals matter. Nat. Immunol. 2007, 8, 1287-1289. [CrossRef]

90. Querfeld, C.; Thompson, J.A.; Taylor, M.; PILLAI, R.K.; DS, L.; JOHNSON, T.C.; Petrova, P.S.; UGER, R.A.; Irwin, M.; Thompson, T. Intralesional Injection of the CD47-blocking immune checkpoint inhibitor TTI-621 (SIRP $\alpha \mathrm{Fc})$ induces antitumor activity in patients with relapsed/refractory mycosis fungoides and Sezary syndrome: Interim results of a multicenter Phase 1 trial. Eur. J. Cancer 2018, 101, S34. [CrossRef]

91. Arai, F.; Hirao, A.; Ohmura, M.; Sato, H.; Matsuoka, S.; Takubo, K.; Ito, K.; Koh, G.Y.; Suda, T. Tie2/angiopoietin-1 signaling regulates hematopoietic stem cell quiescence in the bone marrow niche. Cell 2004, 118, 149-161. [CrossRef] [PubMed]

92. Jones, N.; Iljin, K.; Dumont, D.J.; Alitalo, K. Tie receptors: New modulators of angiogenic and lymphangiogenic responses. Nat. Rev. Mol. Cell Biol. 2001, 2, 257-267. [CrossRef]

93. Venneri, M.A.; De Palma, M.; Ponzoni, M.; Pucci, F.; Scielzo, C.; Zonari, E.; Mazzieri, R.; Doglioni, C.; Naldini, L. Identification of proangiogenic TIE2-expressing monocytes (TEMs) in human peripheral blood and cancer. Blood 2007, 109, 5276-5285. [CrossRef] [PubMed]

94. Diéras, V.; Wildiers, H.; Jassem, J.; Dirix, L.Y.; Guastalla, J.-P.; Bono, P.; Hurvitz, S.A.; Gonçalves, A.; Romieu, G.; Limentani, S.A. Trebananib (AMG 386) plus weekly paclitaxel with or without bevacizumab as first-line therapy for HER2-negative locally recurrent or metastatic breast cancer: A phase 2 randomized study. Breast 2015, 24, 182-190. [CrossRef] [PubMed]

95. Mooi, J.; Chionh, F.; Savas, P.; Duarte, J.D.G.; Chong, G.; Brown, S.; Wong, R.; Price, T.; Wann, A.; Skrinos, E. Dual anti-angiogenesis agents bevacizumab plus trebananib, without chemotherapy, in first-line treatment of metastatic colorectal cancer: Results of a phase II study. Clin. Cancer Res. 2021. [CrossRef] [PubMed]

96. Kaufman, P.A.; Freyer, G.; Kemeny, M.; Goncalves, A.; Jerusalem, G.H.M.; Stopeck, A.; Vrindavanam, N.; Dalenc, F.; Nanayakkara, N.; Wu, B. A Phase $1 b$ Study of Trebananib Plus Paclitaxel (P) and Trastuzumab (T) in Patients (PTS) with Her2+ Locally Recurrent or Metastatic Breast Cancer (MBC); American Society of Clinical Oncology: Alexandria, VA, USA, 2014.

97. Hidalgo, M.; Martinez-Garcia, M.; Le Tourneau, C.; Massard, C.; Garralda, E.; Boni, V.; Taus, A.; Albanell, J.; Sablin, M.-P.; Alt, M. First-in-human phase I study of single-agent vanucizumab, a first-in-class bispecific anti-angiopoietin-2/anti-VEGF-A antibody, in adult patients with advanced solid tumors. Clin. Cancer Res. 2018, 24, 1536-1545. [CrossRef] [PubMed]

98. Bendell, J.C.; Sauri, T.; Gracián, A.C.; Alvarez, R.; López-López, C.; García-Alfonso, P.; Hussein, M.; Miron, M.L.L.; Cervantes, A.; Montagut, C. The McCAVE Trial: Vanucizumab plus mFOLFOX-6 Versus Bevacizumab plus mFOLFOX-6 in Patients with Previously Untreated Metastatic Colorectal Carcinoma (mCRC). Oncology 2020, 25, e451. [CrossRef] [PubMed]

99. Gordon, S.R.; Maute, R.L.; Dulken, B.W.; Hutter, G.; George, B.M.; McCracken, M.N.; Gupta, R.; Tsai, J.M.; Sinha, R.; Corey, D. PD-1 expression by tumour-associated macrophages inhibits phagocytosis and tumour immunity. Nature 2017, 545, 495-499. [CrossRef]

100. Peranzoni, E.; Lemoine, J.; Vimeux, L.; Feuillet, V.; Barrin, S.; Kantari-Mimoun, C.; Bercovici, N.; Guerin, M.; Biton, J.; Ouakrim, H.; et al. Macrophages impede CD8 T cells from reaching tumor cells and limit the efficacy of anti-PD-1 treatment. Proc. Natl. Acad. Sci. USA 2018, 115, E4041-E4050. [CrossRef] [PubMed]

101. Shi, G.; Yang, Q.; Zhang, Y.; Jiang, Q.; Lin, Y.; Yang, S.; Wang, H.; Cheng, L.; Zhang, X.; Li, Y.; et al. Modulating the Tumor Microenvironment via Oncolytic Viruses and CSF-1R Inhibition Synergistically Enhances Anti-PD-1 Immunotherapy. Mol. Ther. J. Am. Soc. Gene Ther. 2019, 27, 244-260. [CrossRef] [PubMed]

102. De Palma, M.; Lewis, C.E. Macrophages limit chemotherapy. Nature 2011, 472, 303-304. [CrossRef]

103. Mitchem, J.B.; Brennan, D.J.; Knolhoff, B.L.; Belt, B.A.; Zhu, Y.; Sanford, D.E.; Belaygorod, L.; Carpenter, D.; Collins, L.; PiwnicaWorms, D.; et al. Targeting tumor-infiltrating macrophages decreases tumor-initiating cells, relieves immunosuppression, and improves chemotherapeutic responses. Cancer Res. 2013, 73, 1128-1141. [CrossRef] [PubMed]

104. Poh, A.R.; Ernst, M. Targeting Macrophages in Cancer: From Bench to Bedside. Front. Oncol. 2018, 8, 49. [CrossRef] [PubMed]

105. Tap, W.D.; Gelderblom, H.; Palmerini, E.; Desai, J.; Bauer, S.; Blay, J.-Y.; Alcindor, T.; Ganjoo, K.; Martín-Broto, J.; Ryan, C.W.; et al. Pexidartinib versus placebo for advanced tenosynovial giant cell tumour (ENLIVEN): A randomised phase 3 trial. Lancet 2019, 394, 478-487. [CrossRef] 
106. Binnemars-Postma, K.; Storm, G.; Prakash, J. Nanomedicine Strategies to Target Tumor-Associated Macrophages. Int. J. Mol. Sci. 2017, 18, 979. [CrossRef]

107. Miller, M.A.; Zheng, Y.R.; Gadde, S.; Pfirschke, C.; Zope, H.; Engblom, C.; Kohler, R.H.; Iwamoto, Y.; Yang, K.S.; Askevold, B.; et al. Tumour-associated macrophages act as a slow-release reservoir of nano-therapeutic Pt(IV) pro-drug. Nat. Commun. 2015, 6, 8692. [CrossRef]

108. Zanganeh, S.; Hutter, G.; Spitler, R.; Lenkov, O.; Mahmoudi, M.; Shaw, A.; Pajarinen, J.S.; Nejadnik, H.; Goodman, S.; Moseley, M. Iron oxide nanoparticles inhibit tumour growth by inducing pro-inflammatory macrophage polarization in tumour tissues. Nat. Nanotechnol. 2016, 11, 986. [CrossRef] [PubMed] 